\title{
Climatic influence on fire regime (1700 to 2008) in the Nazas watershed, Durango, Mexico
}

\author{
Julián Cerano-Paredes ${ }^{1,2}$, José Villanueva-Díaz ${ }^{1}$, Lorenzo Vázquez-Selem², Rosalinda Cervantes-Martínez ${ }^{1}$, \\ Víctor O. Magaña-Rueda², Vicenta Constante-García', Gerardo Esquivel-Arriaga ${ }^{1}$ and Ricardo D. Valdez-Cepeda ${ }^{3,4^{*}}$
}

\begin{abstract}
Background: Fire scars are the primary source of physical evidence used to date past fires around the world, and to estimate parameters of historical fire regimes and fire-climate relationships. Despite an increase in studies about historical fire regimes and the relationship between fire and climate, these studies are still limited for Mexican forests. Our goal was to characterize the historical fire regime in two sites with different elevations, to assess changes in fire frequency, and to determine the relationship between fire regimes and climate patterns in a conifer-dominated forest in the Upper Nazas watershed of the Sierra Madre Occidental, Mexico. We were able to cross-date 50 fire-scarred samples of Pinus arizonica Engelm., P. strobiformis Engelm., P. teocote Schlecht. \& Cham., P. durangensis Martínez, and Pseudotsuga menziesii (Mirb.) Franco and identify a total of 596 fire scars.

Results: Evidences are compelling evidences on forest fires occurred frequently in the study area, starting in the mid eighteenth century and through the mid twentieth century. The season of fire occurrence was determined for $560(94 \%)$ fire scars. Most fire scars at both of our sampling locations, found at low and high elevation sites, occurred in the spring $(525,93.8 \%)$ and only $6.2 \%$ occurred in the summer. The mean fire interval and Weibull median fire interval values were $<10$ years for all fire-scar filter (all samples, $\geq 10 \%$ and $\geq 25 \%$ ), and the average per-sample fire interval was $<25$ years.

Conclusions: Our results suggest fire frequency has changed over time at our study site, becoming less common and less extensive since the 1950s. In addition, extensive fires occurred in dry years as indicated by low precipitation, negative NIÑO 3 Sea Surface Temperature (SST) values, and negative Palmer Drought Severity Index (PDSI) values. Fire frequencies must be maintained within the amplitude of their historical regime, with the objective of reducing the risk of severe fires and preserving ecological and hydrological benefits in the watershed.
\end{abstract}

Keywords: drought, ENSO, fire history, fire-scar data, forests, PDSI

\section{Introduction}

Forest fire regimes, specifically fire return intervals, frequency, extent, and seasonality, vary over space and time at many scales. Thus, wildfire dynamics have often been related to variations in climate (Swetnam and Betancourt 1990; Heyerdahl and Alvarado 2003; Fulé et

\footnotetext{
* Correspondence: vacrida@hotmail.com

${ }^{3}$ Centro Regional Universitario Centro Norte, Universidad Autónoma Chapingo, Calle Cruz del Sur 100, Col. Constelación, CP 98085 Zacatecas, Zac., Mexico

${ }^{4}$ Unidad Académica de Matemáticas, Universidad Autónoma de Zacatecas, Calzada Solidaridad s/n, CP 98064 Zacatecas, Zac., Mexico

Full list of author information is available at the end of the article
}

al. 2005; Skinner et al. 2008). Large and intense fires are commonly linked to dry years caused by global and regional scale climate-forcing mechanisms such as the $\mathrm{El}$ Niño Southern Oscillation (ENSO), among others (Heyerdahl and Alvarado 2003; Fulé et al. 2005; Skinner et al. 2008; Cerano-Paredes et al. 2010; Yocom et al. 2010). Increasing our understanding of the spatial and temporal connections between fire events and climate variability at various time scales is important to generate information to improve management strategies, such as fire suppression or prescribed burns, among other treatments (Falk et al. 2011). 
Years associated with fire activity appear to result from complex interactions between the phasing of ENSO in the North American mediterranean climatic region (Taylor and Beaty 2005). Fire activity has also been linked to wetter conditions in years preceding fire events (Swetnam and Betancourt 1998; Swetnam and Baisan 2003; Taylor and Beaty 2005). This could be due, in part, to an increased productivity of herbs and grasses in response to greater water availability, which causes the accumulation of fine fuels that facilitate fire spread (Swetnam and Betancourt 1998). In recent decades, fire histories have been developed for sites located in the Sierra Madre Occidental (Fulé and Covington 1997, 1999; Heyerdahl and Alvarado 2003; Fulé et al. 2005; Drury and Veblen 2008; Cerano-Paredes et al. 2010; Molina-Pérez et al. 2017) and the Sierra Madre Oriental (Yocom et al. 2010, 2014), but additional fire history studies are needed to better understand the fire-climate relationship in other forested areas of Mexico, such as the Upper Nazas watershed.

Our study sites were located in the upper watershed of the Nazas and Aguanaval rivers, in northwestern Mexico, from which surface runoff is stored in the Lazaro Cardenas Reservoir (Sánchez-Cohen et al. 2018). The forested headwaters of the Upper Nazas yield nearly $90 \%$ of the water in the basin, which is used for agriculture and industry, as well as other activities, by a population of over one million people in the Comarca Lagunera, located in the lower watershed (Loyer et al. 1993). Changes in forest structure, composition, and dynamics, due to fires or other land-use changes, affect water availability and quality, as well as groundwater recharge (Bruijnzeel 1990; Myers 1997).

Studies in other parts of the world, including Asia (Schweithelm 2005), Brazil (Costa 2005), North America (Daily 2000; Aylward 2005), and Mexico (Descroix et al. 2004; Manson 2004), link forest vegetation in the headwaters to the provision of different ecosystem services at the basin level. Processes in the Upper Nazas invariably have repercussions in the lower part of the watershed, and its forests play an important regulatory role, controlling the quantity and timing of water flow, protecting soils from erosion and fertility loss, while preventing sedimentation and bank degradation (Descroix et al. 2004). However, there is a paucity of information concerning the fire history of the forests of the headwaters of the basin, which is important to provide managers with a technical basis for the development or fine-tuning of fire prevention and management programs.

The objectives of this study were: 1 ) to characterize the historical fire regime in two sites set at different elevations within the Upper Nazas watershed, 2) to assess temporal changes in fire regimes at these two sites, and 3) to determine the relationship between fire regimes and climate patterns within these coniferous forests. We aimed to provide insights for land managers that work in the region with information generated to answer the following questions:

1. What was the seasonality, frequency, and extent of historical fires at these sites?

2. Did fire regimes change in the twentieth century at the study sites?

3. Did climate variation influence the historical fire regime at the study sites?

\section{Methods}

Study area

The study area, Ciénega de la Vaca, is found in the municipality of Tepehuanes, within the Mexican state of Durango (Fig. 1). The Upper Nazas watershed is part of Hydrological Region 36, which encompasses the Nazas and Aguanaval rivers, and has a surface area of $18,321.6 \mathrm{~km}^{2}$ and a perimeter of $1162.1 \mathrm{~km}$ (INEGI 2018).

The Upper Nazas watershed is part of the Sierra Madre Occidental, the longest and most continuous mountain system in Mexico. This range is approximately $1160 \mathrm{~km}$ long and $200 \mathrm{~km}$ wide, and extends from the México-US border to west-central Mexico, between the extreme coordinates $30^{\circ} 35^{\prime} \mathrm{N}$ to $21^{\circ} 00^{\prime} \mathrm{N}$, and $-109^{\circ} 10^{\prime} \mathrm{W}$ to $-102^{\circ} 25^{\prime} \mathrm{W}$ (González-Elizondo et al. 2012).

Conifers such as Pinus arizonica Engelm., P. strobiformis Engelm., P. teocote Schlecht. \& Cham., P. durangensis Martínez, and Pseudotsuga menziesii (Mirb.) Franco are abundant elements of forests in the study area (Farjon et al. 1997; González-Elizondo et al. 2012). The predominant climate is classified as sub-humid temperate type with summer rains (Cw; García 1987). Annual mean precipitation ranges between 470 and $500 \mathrm{~mm}$; winter precipitation accounts for $12.8 \%$ $(60 \mathrm{~mm})$ of the annual total, while summer precipitation accounts for $78.5 \%(369 \mathrm{~mm})$ of the annual total. Mean annual temperature is $10{ }^{\circ} \mathrm{C}$, with a high monthly mean temperature of $30{ }^{\circ} \mathrm{C}$ (May or June); the monthly low mean temperature occurs in January (IMTA 2009).

\section{Field work}

We sampled two sites at different elevations: a low elevation site (LS), located between 2560 and 2680 masl, and a high elevation site (HS), located between 2860 and 2930 masl (Table 1). The sampled area at the LS was 50 ha, and at the HS was 25 ha. We selected the study sites based on presence of old trees and availability of remnant wood, in order to build the longest possible tree-ring record (Fig. 2). Intensive logging in past years at HS did not allow us to find live trees with fire scars, limiting our sampling to dead material, which affected the sample depth. At LS, we sampled fire-scarred trees from live and dead specimens (including logs, snags, and 


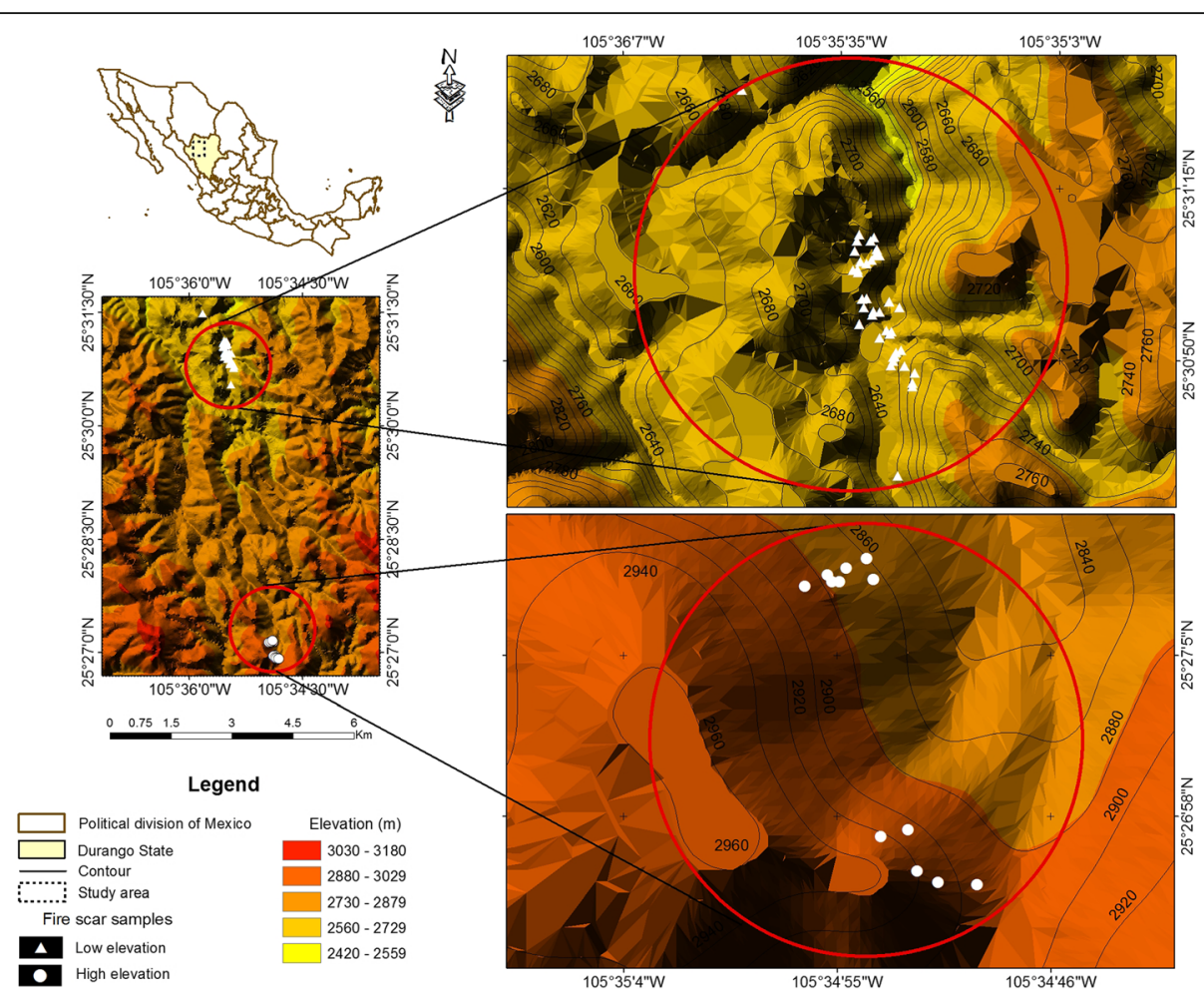

Fig. 1 Location of the study area (Upper Nazas watershed) in northwestern Durango, Mexico. The map shows the Ciénega de la Vaca area and the two sampling sites

stumps) using a chainsaw to cut cross-sections. We selected samples from well-preserved old trees with visible fire scars (Arno and Sneck 1977); young trees with few scars were also included to ensure that the fire history extended up to the present. In some instances, several fire-scarred sections were collected from one tree and later combined for the analysis at tree scale. All fire-scarred sections were transported to and processed at the Laboratorio de Dendrocronología, at Instituto Nacional de Investigaciones Forestales Agrícolas y Pecuarias, Gomez Palacio, Durango.

\section{Laboratory methods}

Fire-scarred samples were sanded with progressive grains to highlight cell structure under a microscope with 10 to $30 \times$ magnification. Calendar years were assigned to tree rings using a combination of visual cross-dating of ring widths, other anatomical features of the ring, and cross-correlation of measured ring-width

Table 1 Study site characteristics for the Ciénega de la Vaca, Durango, Mexico

\begin{tabular}{lccc}
\hline Study site & Site code & Elevation (m) & Average slope (\%) \\
\hline Low elevation site & LS & 2560 to 2680 & 50 \\
High elevation site & HS & 2860 to 2930 & 34 \\
\hline
\end{tabular}

series (Stokes and Smiley 1968). We used an existent Pseudotsuga menziesii ring-width chronology from the Nazas watershed for cross-dating purposes (Cerano-Paredes et al. 2012). Ring widths for all samples were measured using the Velmex system (Robinson and Evans 1980) and quality-dating verified with the COFECHA program (Holmes 1983). The season of fire occurrence was estimated based on the relative position of each fire lesion within the annual ring according to the following categories: Early Earlywood (EE), Middle Earlywood (ME), Late Earlywood (LE), Latewood (L), and Dormant or ring boundary (D) (Dieterich and Swetnam 1984; Baisan and Swetnam 1990). The intra-ring locations were grouped into two categories for further analysis: 1) spring $(\mathrm{EE}+\mathrm{D})$ and 2) summer $(\mathrm{ME}+\mathrm{LE}+\mathrm{L})$ (Fulé and Covington 1999; Grissino-Mayer 2001).

Fire history data were analyzed using the FHX2 software, version 3.2 (Grissino-Mayer 2001). Analysis for each site started with the first year that had an adequate sample depth, defined as the first fire year recorded by $10 \%$ or more of the total number of recording trees at each elevation site (Fulé et al. 2012). Recording trees were those with open fire scars or those that were affected by other injuries, such as lightning scars, leaving them susceptible to repeated scarring by fire. The last date for the analysis was 2008, since it showed the last complete ring before sampling. 


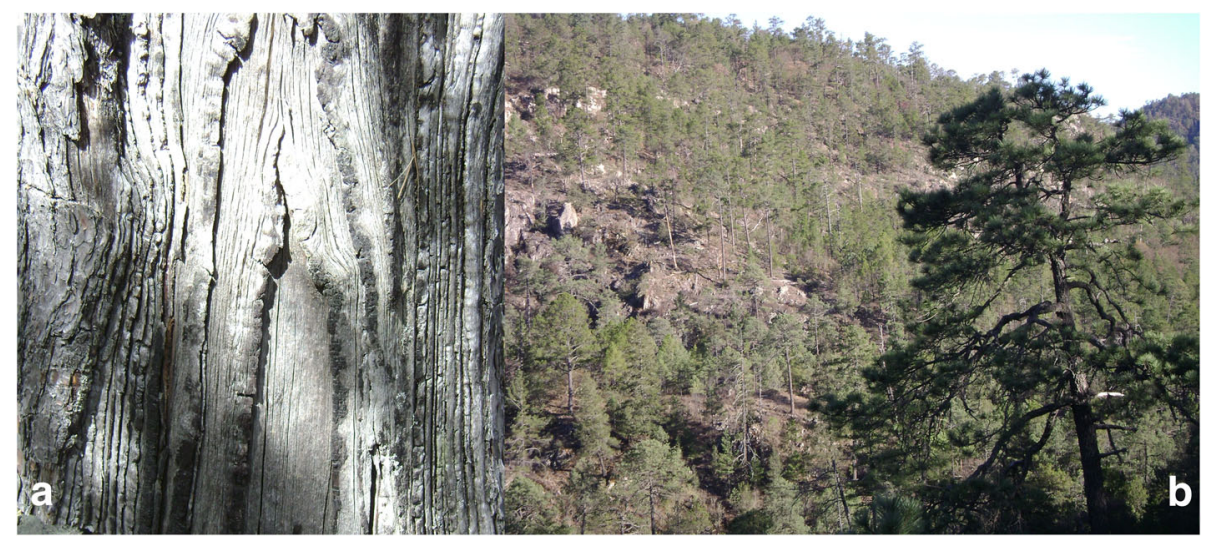

Fig. 2 a Pinus strobiformis tree with excellent records of fire scars, and $\mathbf{b}$ view of forest ecological conditions at the Upper Nazas watershed, Durango, Mexico

\section{Fire data analysis}

Fire return intervals were described using three filters: all scars, $\geq 10 \%$ scarred, and $\geq 25 \%$ scarred. These filters were used because the all-scar filter involves every single fire year recorded in the sample set, but not all the fires that burned the sites are present, as pointed out by Farris et al. (2010). The $\geq 10 \%$ filter eliminates years with the most minimal scarring, but still represents a relatively high estimate of fire frequency; the $\geq 25 \%$ filter is widely used as an estimate of fire frequency, which assumes that those fires were relatively large (Swetnam and Baisan 1996). Fire interval distributions are typically non-normal, so we fit Weibull models to the empirical fire-interval distributions and tested for adequate fit. We then calculated the Mean Fire Interval (MFI), Minimum and Maximum Fire Interval (MinFI and MaxFI, respectively), and Weibull Median Probability Intervals (WMPI) for each site (Grissino-Mayer et al. 1994; Swetnam and Baisan 1996).

\section{Fire-climate Relationships}

We used Superposed Epoch Analysis (SEA) to examine the relationship between fire occurrence and climate by using three climatic series (Baisan and Swetnam 1995; Grissino-Mayer and Swetnam 2000): 1) a reconstructed winter to spring precipitation (1599 to 2008, 410 yr., Cerano-Paredes et al. 2012), 2) reconstructed NIÑO 3 SST indices (December to February, 1408 to 1978; Cook 2000a), and 3) the reconstructed Palmer Drought Severity Index (PDSI), grid point \#63 (1690 to 1978), the nearest one to the study area (Cook 2000b).

The SEA is a statistical method that compares climate data with fire dates by superposing windows of concurrent and lagged climatic conditions for each recorded fire (Swetnam 1993; Grissino-Mayer 2001).
For each fire year, we used average annual climate conditions during fire years, for five years prior to the fire year, and two years after the fire year. We compared precipitation, ENSO, and PDSI indices with the occurrence of all fires regardless of size, as well as widespread fires that scarred at least $10 \%$ and $25 \%$ of recording trees for the two sites. We completed these analyses for the entire period that had an adequate tree-ring record (1739 to 2008). Significant climate departures were identified as those exceeding 95, 99 and $99.5 \%$ confidence intervals by bootstrapping (1000 trials, Grissino-Mayer 2001) through Monte Carlo simulations.

To identify possible interrelationships between the NIÑO 3 SST index and the reconstructed winter-spring precipitation index, Wavelet Coherence Analysis (WCA) was carried out with MATLAB 6.5 (MathWorks 2002). This analysis allows one to determine the wavelet coherence, which is a kind of correlation, between the two signals in both time and frequency domains. In addition, we used the Mexican Drought Atlas (Stahle et al. 2016) to generate maps displaying climatic conditions during the largest fire years.

\section{Results}

We collected a total of 68 fire-scarred samples from four species: Pinus arizonica, P. strobiformis, P. teocote, and Pseudotsuga menziesii; 46 of the samples were taken from LS and 22 from HS. Most trees (74\%) consisted of dead material (snags, logs, or stumps); the remaining samples (26\%) came from living trees (Table 2). Of the 68 fire-scarred trees, 50 (74\%) were successfully crossdated, revealing 596 fire scars (Table 3). Cross-dating of 18 (26\%) fire-scarred trees was not possible due to decayed wood, presence of very compressed rings, or an insufficient number of rings that inhibited reliability. 
Table 2 Characteristics of sampled trees in the Ciénega de la Vaca, Durango, Mexico. ${ }^{1}$ Tree species are Pinus arizonica (Par), Pinus strobiformis (Pst), Pinus teocote (Pte), and Psedotsuga menziesii (Psm)

\begin{tabular}{|c|c|c|c|c|c|c|c|}
\hline Site & $\begin{array}{l}\text { Samples } \\
\text { collected }(n)\end{array}$ & $\begin{array}{l}\text { Used in the } \\
\text { study }(n)\end{array}$ & $\begin{array}{l}\text { Living } \\
(n)\end{array}$ & $\begin{array}{c}\text { Snag or log } \\
(n)\end{array}$ & $\begin{array}{l}\text { Cut stump } \\
(n)\end{array}$ & Species $^{1}$ & $\begin{array}{l}\text { Average } \\
\text { diameter }(\mathrm{cm})\end{array}$ \\
\hline Low & 46 & 33 & 10 & 16 & 7 & Par, Pst, Pte, Psm & 45.9 \\
\hline High & 22 & 17 & 0 & 7 & 10 & Par, Pst & 46.4 \\
\hline Combined & 68 & 50 & 10 & 23 & 17 & & \\
\hline
\end{tabular}

\section{Fire extent, frequency, and seasonality}

Two of the more recent fires occurred in 1982 and 1998 at the LS. The last fire was recorded in a single tree, suggesting a small fire. The earliest fires occurred in 1582 and 1584 at HS, and 1696 and 1699 at LS (Fig. 3). The first widespread fire recorded at both sites occurred in 1729. In addition, 12 other widespread fires occurred, the last one in 1951.

Fire frequencies were reduced drastically following 1951, particularly extensive fires that burned $\geq 25 \%$ of the scarred trees. For example, no extensive fires $(\geq 25 \%$ scarred) were recorded from 1951 to 2008 (a 57-year interval) at the HS site. Meanwhile, at the LS site, intervals without extensive fires ( $\geq 25 \%$ scarred) took place from 1951 to 1982 (31-year interval) and 1983 to 2008 (26-year interval) (Fig. 3).

Fires were frequent in the Upper Nazas watershed over the past centuries (Table 4): for all scars (combining both sites, periods 1739 to 1982 and 1739 to $1954)$, the MFI and WMPI were $<3$ years. For extensive fires ( $\geq 25 \%$ scarred), the MFI and WMPI were generally between 7 to 9 years and 6 to 8 years, for LV and $\mathrm{HS}$, respectively. Averages of per-tree fire intervals were all between 15 to 17 years regardless of the site. For small fires, the minimum fire-free intervals were 1 to 2 years. Although LS and HS are several kilometers apart (Fig. 1), fire dates in many years were synchronous across sites (Fig. 3). Widespread fires occurred consistently from 1729 to 1951; both sites (LS and HS) recorded fires during the same years in 1729, 1807, 1818, 1854, 1886, 1890, 1901, 1904, 1927, and 1951.

We determined seasonality of 560 (94\%) fire scars (Table 3). The most common seasonal position was EE (525 scars, 93.8\%), followed by ME (33 scars, 5.9\%), and LE (2 scars, 0.4\%). Fire scars were not found in the dormant (D) or latewood (L) seasons (Table 3).

\section{Fire-climate relationship}

Results from SEA analyses indicate that years in which more extensive fires occurred were dry and preceded by wet years (Fig. 4). These results are indicated by a significantly lower winter to spring precipitation on the actual fire year $(P<0.01$ for $\geq 10 \%$ filter, and $P<0.05$ for $\geq 25 \%$ filter; Fig. $4 b, c)$. In addition, observed precipitation was significantly greater than normal one year prior to the fire year $(P<0.01$ for all scars filter, $P<0.05$ for $\geq 10 \%$ filter, and $P<0.001$ for $\geq 25 \%$ filter). The SEA also showed that extensive fire years occurred when NIÑO 3 SST indices were negative (Fig. 5). The NIÑO 3 SST indices were significantly dry $(P<0.01$ for $\geq 10 \%$, and $P<0.05$ for $\geq 25 \%$ filters; Fig. 5b, c) during extensive fire years. Moreover, significantly positive NIÑO 3 SST indices suggest that one year $(P<0.05$ for $\geq 10 \%$ filter; Fig. $5 b)$ and four years prior to the fire year, conditions were

Table 3 Determination of the seasonality of fire scars (number and percent) based on the position of the fire lesion within the scarred ring, for Ciénega de la Vaca, Durango, Mexico, for 1575 to 2008. D dormant, EE early earlywood, ME middle earlywood, LE late earlywood, and $L$ latewood

\begin{tabular}{|c|c|c|c|c|c|c|c|c|c|}
\hline Site and analysis period & Season determined & Season undetermined & $\mathrm{D}$ & $\mathrm{EE}$ & ME & $\mathrm{LE}$ & $\mathrm{L}$ & Spring fires & Summer fires \\
\hline \multicolumn{10}{|c|}{ Low elevation site 1670 to 2008} \\
\hline Number $(n)$ & 334 & 21 & 0 & 304 & 29 & 1 & 0 & 304 & 30 \\
\hline Percentage (\%) & 94.1 & 5.9 & 0 & 91.0 & 8.7 & 0.3 & 0 & 91.0 & 9.0 \\
\hline \multicolumn{10}{|c|}{ High elevation site 1575 to 1994} \\
\hline Number $(n)$ & 226 & 15 & 0 & 221 & 4 & 1 & 0 & 221 & 5 \\
\hline Percentage (\%) & 93.8 & 6.2 & 0 & 97.8 & 1.8 & 0.4 & 0 & 97.8 & 2.2 \\
\hline \multicolumn{10}{|c|}{ Combined sites 1575 to 2008} \\
\hline Number $(n)$ & 560 & 36 & 0 & 525 & 33 & 2 & 0 & 525 & 35 \\
\hline Percentage (\%) & 94.0 & 6.0 & 0 & 93.8 & 5.9 & 0.4 & 0 & 93.8 & 6.2 \\
\hline
\end{tabular}




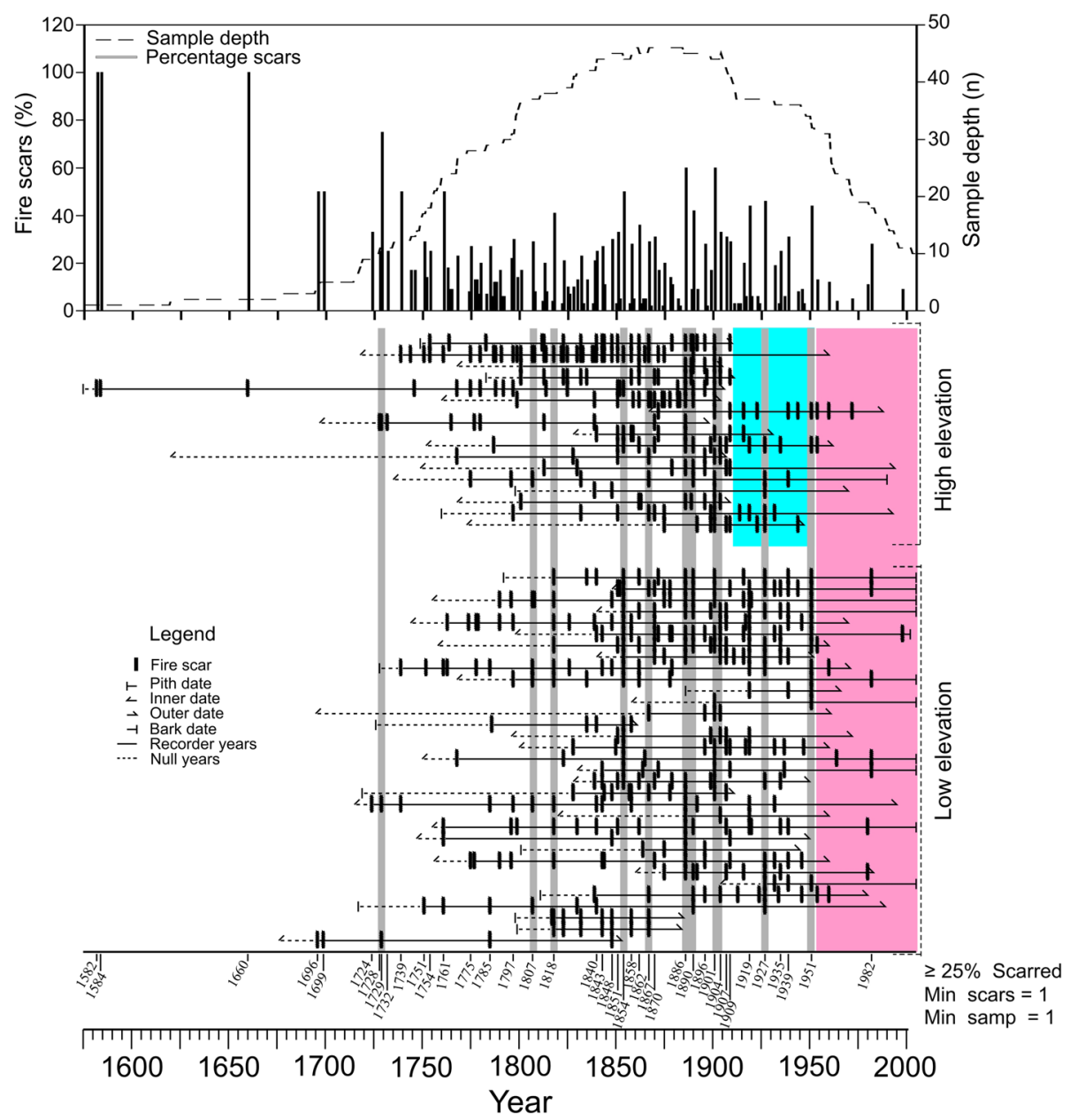

Fig. 3 Fire history chart for the low-elevation site and the high-elevation site along the elevation gradient on the Upper Nazas watershed for the period 1575 to 2008. Date is on the $x$-axis, horizontal lines represent each sample, vertical black lines represent fire scars, and the gray lines show widespread fires affecting both sites. The pink band indicates a long period (50 years) with low fire occurrence, while the blue band indicates low fire variability that started 100 years ago at the high-elevation site

relatively wet $(P<0.05$ for $\geq 25 \%$ filter; Fig. 5 c $)$. The SEA also indicates that extensive fires occurred when PDSI values were negative, which means severe drought $(P<0.05$ for both $\geq 10 \%$ and $\geq 25 \%$ filters; Fig. $6 \mathrm{~b}, \mathrm{c})$. In addition, PDSI maps for the years 1818, 1854, 1890, 1901, 1951, and 1982 show that these years were characterized by dominant dry conditions (Fig. 7).

\section{Wavelet coherence analysis}

To support the climate-ENSO relationship, we conducted a wavelet coherence analysis. The results suggest that winter-spring precipitation in the study area is strongly $\quad(P<0.05) \quad$ modulated by the ENSO phenomenon. Significant areas of coherence were found for the period from 1600 to 1978 at frequencies of 1 to 14 years (Fig. 8).

\section{Discussion}

With what seasonality, frequency, and extent did surface fire formerly burn?

Forest fires occurred frequently in the study area from the mid eighteenth century to the mid twentieth century. Most of these fires (>90\%) occurred during the early spring. The general estimated MFI and WMPI (3 to 8 years) for both sites are similar to fire reconstructions for pine-oak forests in different locations in the Durango portion of the Sierra Madre Occidental, where Fule and Covington (1997, 1999), Heyerdahl and Alvarado (2003), and Drury and Veblen (2008) reported MFI and WMPI values that range from 3 to 6 years. Fulé et al. (2005) and Cerano-Paredes et al. (2010) observed similar fire intervals (3 to 5 years) in Chihuahua's Sierra Madre Occidental.

A majority of fires in this study appear to have burned in the spring or during early wood development (525 fires, 93.8\%), suggesting that it is likely that they took 
Table 4 Statistics of fire interval distributions for Ciénega de la Vaca, Durango, Mexico, from 1739 to 1982. Statistical analysis was carried out in three categories: (1) all fire years, including those represented by a single fire scar; (2) fire years in which 10\% or more of the recording sample trees were scarred; and (3) fire years in which $25 \%$ or more of the recording sample trees were scarred. MFI mean fire interval, Min minimum fire interval, Max maximum fire interval, WMPI Weibull median probability interval

\begin{tabular}{|c|c|c|c|c|c|c|c|}
\hline $\begin{array}{l}\text { Site and } \\
\text { analysis period }\end{array}$ & $\begin{array}{l}\text { Category of } \\
\text { analysis }\end{array}$ & Intervals & MFI (yr) & Min (yr) & $\operatorname{Max}(y r)$ & $\begin{array}{l}\text { Average } \\
\text { per-sample } \\
\text { fire interval } \\
\text { (yr) }\end{array}$ & WMPI \\
\hline \multirow[t]{3}{*}{ Low elevation site 1739 to 1982} & All scars & 77 & 3.16 & 1 & 16 & 16.9 & 2.69 \\
\hline & $10 \%$ scarred & 56 & 4.34 & 1 & 20 & & 3.73 \\
\hline & $25 \%$ scarred & 28 & 8.68 & 1 & 31 & & 7.22 \\
\hline \multirow[t]{3}{*}{ Low elevation site 1739 to 1954} & All scars & 73 & 2.95 & 1 & 12 & 16.4 & 2.59 \\
\hline & $10 \%$ scarred & 53 & 4.00 & 1 & 12 & & 3.60 \\
\hline & $25 \%$ scarred & 27 & 7.85 & 1 & 22 & & 6.80 \\
\hline \multirow[t]{3}{*}{ High elevation site 1739 to 1954} & All scars & 76 & 2.63 & 1 & 7 & 13.0 & 2.45 \\
\hline & $10 \%$ scarred & 60 & 3.33 & 1 & 9 & & 3.14 \\
\hline & $25 \%$ scarred & 32 & 6.25 & 1 & 19 & & 5.44 \\
\hline \multirow[t]{3}{*}{ Combined 1739 to 1982} & All scars & 107 & 2.27 & 1 & 8 & 15.6 & 2.04 \\
\hline & $10 \%$ scarred & 62 & 3.92 & 1 & 20 & & 3.44 \\
\hline & $25 \%$ scarred & 30 & 8.10 & 2 & 31 & & 6.97 \\
\hline \multirow[t]{3}{*}{ Combined 1739 to 1954} & All scars & 102 & 2.11 & 1 & 7 & 15.3 & 1.94 \\
\hline & $10 \%$ scarred & 59 & 3.64 & 1 & 12 & & 3.37 \\
\hline & $25 \%$ scarred & 29 & 7.31 & 2 & 22 & & 6.61 \\
\hline
\end{tabular}

place before the start of the rainy season, with only a few fires recorded in the summer (35 fires, 6.2\%). Thus, we concluded that, in this region, the onset of the summer rains causes surface fuels to be too wet to burn, while annual species begin to green up, restricting fire spread; this has been recorded in other parts of the Sierra Madre Occidental (Heyerdahl and Alvarado 2003). Fire-scar evidence suggests that forest fires in the Sierra Madre Occidental, historically, have occurred during the dry spring, when lightning is common, providing an ignition source for fine fuels, which are often dry at that time of the year (Douglas et al. 1993; Heyerdahl and Alvarado 2003).

\section{Did the fire regime change in the twentieth century?}

Our results indicated that a large shift in fire frequency and extent occurred after 1950; fire-free intervals during this span were the longest in the last 300 years for each site. The trend of frequent, synchronous fires was altered in the mid twentieth century at both sites, which we attribute to land-use changes and not to a change in climate. The primary reason for fire exclusion in northern Mexico is believed to be land-use change, especially increased livestock grazing, associated with land redistribution following the Mexican Revolution (Fulé et al. 2005). These results are consistent with those presented by
Fulé and Covington (1997, 1999), Heyerdahl and Alvarado (2003), and Cortes-Montaño et al. (2012) for other regions of the Sierra Madre Occidental. These authors identified fire regime changes or fire exclusion starting in the mid twentieth century. Several authors (e.g., Fulé and Covington 1997, 1999; Kaib 1998; Heyerdahl and Alvarado 2003) have proposed that changes in land use-the construction of rural roads for cattle grazing and logging at high-elevation sites, and the development of rain-fed agriculture at lower elevation sites-affected fuel continuity that may have resulted in fire frequency changes. Although these land uses have a long history in the study area, their impact has increased greatly since the 1970s (Descroix et al. 2004).

Did climate variations influence the historical fire regime? Climate dynamics have historically influenced the occurrence and extent of fires in the forests of Ciénega de la Vaca, as evidenced by the strong relationship found between widespread fires and the regional reconstructed precipitation, ENSO 3 SST indices, and PDSI values. It has been widely recognized that the ENSO pattern is the most important driver of seasonal and interannual climatic variability at global, regional, and local scales (Wolter and Timlin 2011). Our results suggest that ENSO has modulated seasonal precipitation in the study area in the past 


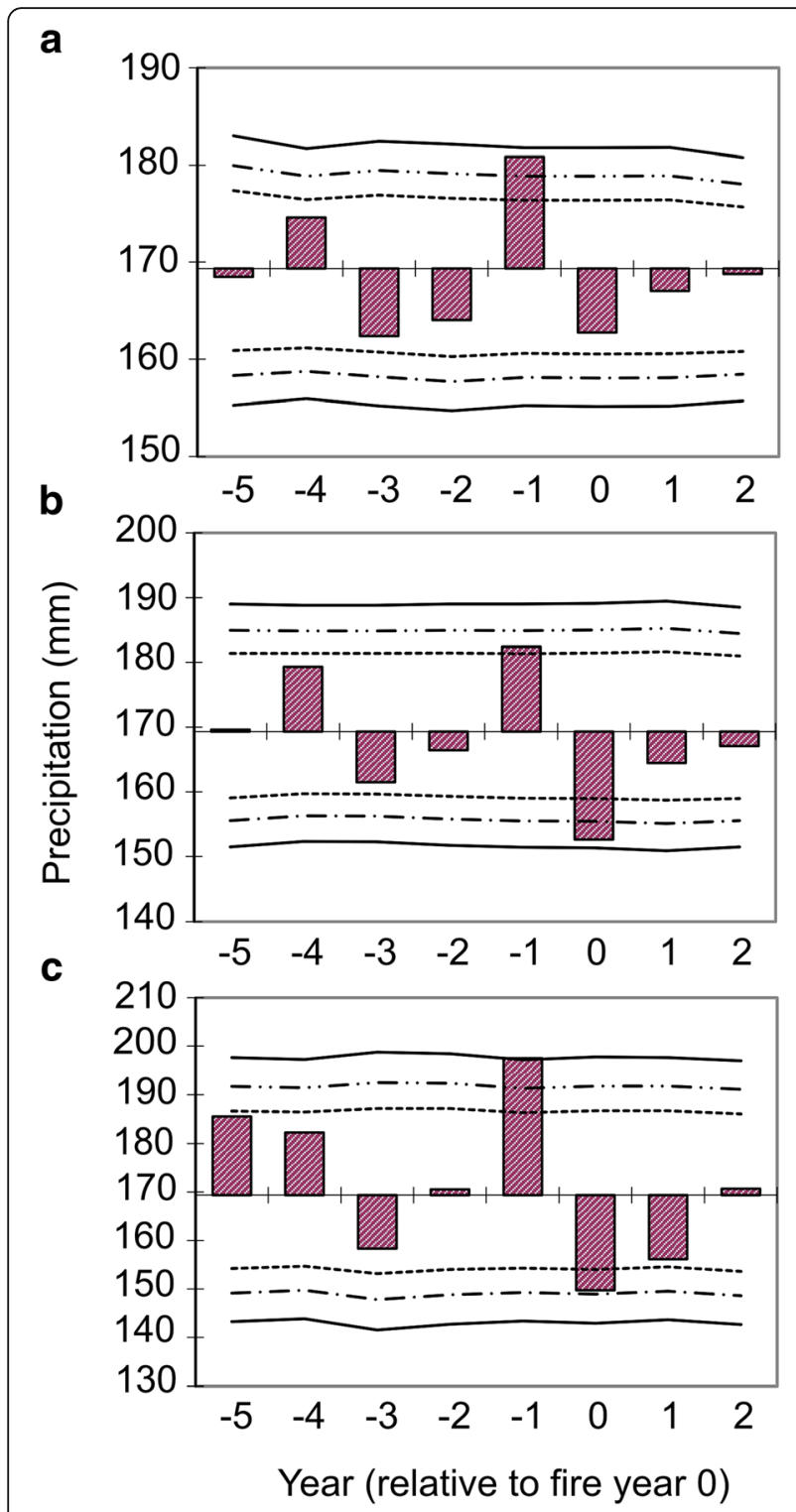

Fig. 4 Superposed Epoch Analysis (SEA) charts showing the relationship between reconstructed winter-spring precipitation for the Upper Nazas watershed (Cerano-Paredes et al. 2012) and fire years listed in Fig. 3. a all fires, $\mathbf{b}$ fires with $\geq 10 \%$ scarred trees, and $\mathbf{c}$ fires with $\geq 25 \%$ scarred trees. The fire year is indicated by 0 . The horizontal line in each panel marks significant departures based on bootstrapped confidence intervals (dotted $=P<0.05$; dashed $=P<0.01$; solid $=P<0.001$ )

400 years, which we corroborated with the WCA analysis (1400 to 1978). Moreover, they align with those of Stahle et al. (1998), Magaña (1999), and Cerano-Paredes et al. (2011) regarding the influence of ENSO on interannual and multiannual precipitation variability in northern Mexico, where the warm phase of the oscillation (El Niño) produces above-normal winter rains, while the cold phase (La Niña) favors dry conditions (Magaña et al. 2003; Caso et al. 2007).

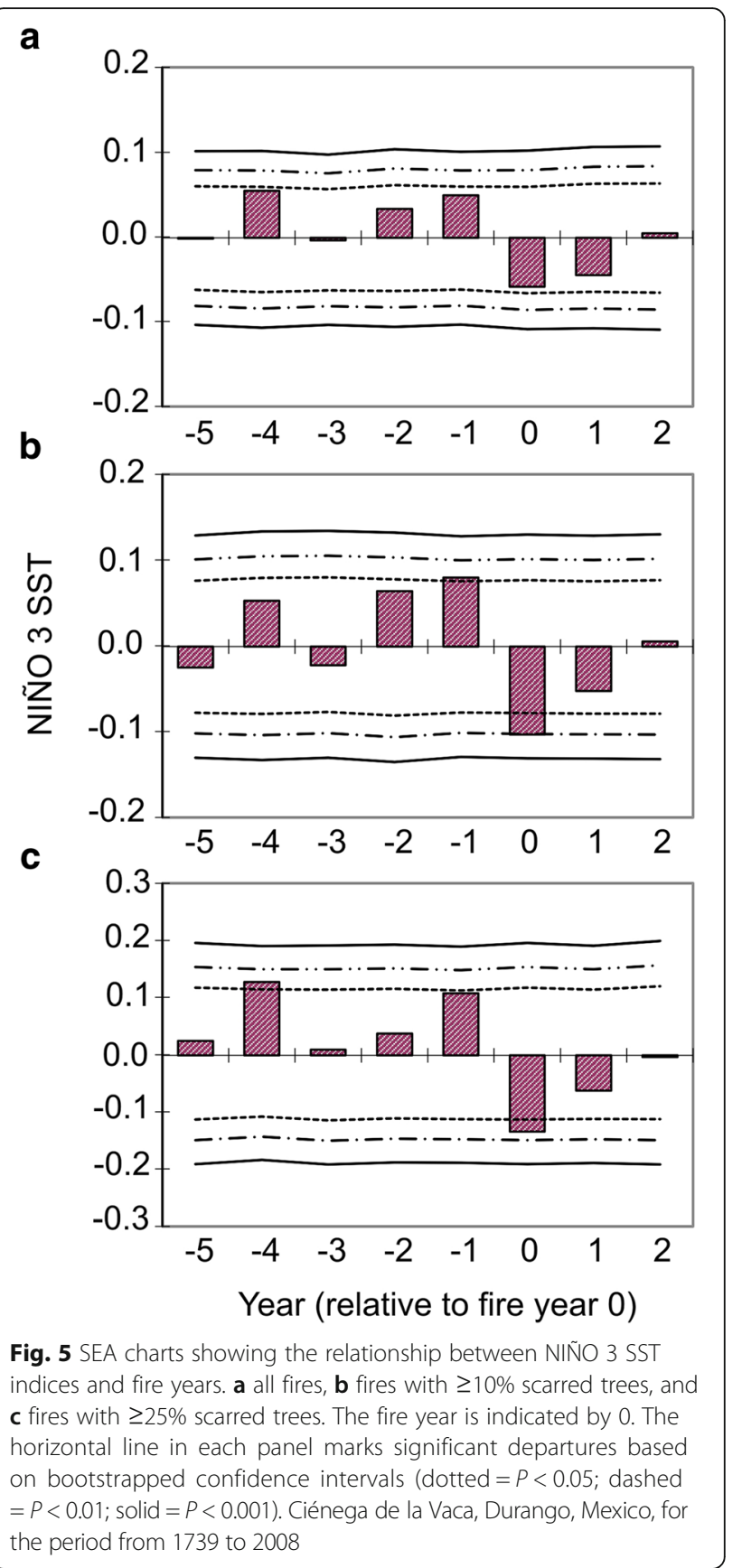

Our results show that frequent fires occurred between 1700 and 1954 in Ciénega de la Vaca. Extensive wildfires were probably influenced by ENSO, particularly in its La Niña phase, while the El Niño phase tended to produce wetter conditions, leading to greater production of fine fuels, which dried out during subsequent dry years, allowing fires to start and spread out over larger areas. This wet-and-dry cycle probably increased the probability of extensive fires in the region (Drury and Veblen 2008). 


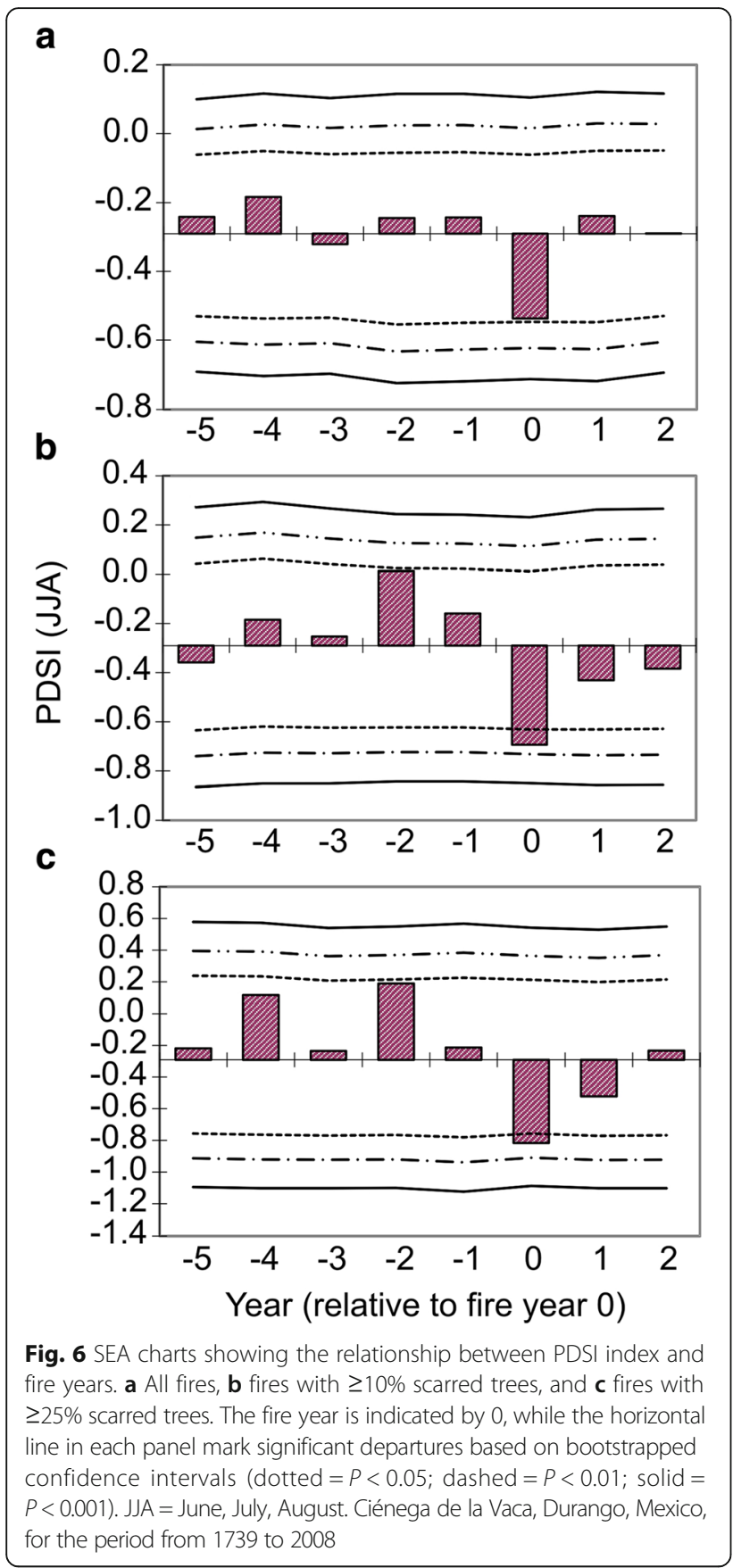

Dry conditions, as determined by PDSI indices, could also be related to the frequency of forest fires at the study site. Historically, extensive fires occurred when PDSI values were negative, suggesting that the area was undergoing severe drought. Although we did not find a significant link between PDSI and antecedent conditions for extensive fires, the preceding high PDSI values (wet conditions) presented a positive relationship (Fig. 6), and the antecedent precipitation was highly significant (Fig. 4). There is a clear link between antecedent moisture one (Figs. 4 and 5) and two years (Fig. 6) preceding a fire, which leads to greater production of fine fuels, and dry conditions during subsequent dry years, and fire presence (Figs. 4, 5, and 6).

\section{Management implications}

Our data support the hypothesis that wildfires were relatively frequent in our study site, similar to the findings of studies in other parts of North America such as southern Arizona, USA (Iniguez et al. 2016), southwestern Colorado, USA (Brown and Wu 2005), and northern Colorado, USA (Brown et al. 2015). It is likely that fires have played an important role in conifer forest dynamics in the Upper Nazas, where fire regimes were similar at different elevations (LS, HS). This could indicate that extensive fires have affected the entire altitudinal gradient, implying an influence of climate on the spatial synchrony of fire occurrence. Fire regimes reflect a complex interplay of bottom-up and top-down controls (Lertzman et al. 1998). Bottom-up controls include local variations in topographic, fuel, and weather factors at the time of a burn. Climate is the primary top-down control of fire regimes, acting largely through inter-annual regulation of biomass production, fuel moisture, and regional ignition patterns. Top-down regulation leads to spatial and temporal synchrony in fire occurrence (Falk et al. 2010).

A significant change in fire frequency occurred in the watershed after the 1950s, perhaps related to land-use changes. This has increased the risk and susceptibility of these forests to maintain forest dynamics, hydrological functions, forest productivity, and other ecosystem services. This change in fire frequency is not exclusive to the study area; studies in other locations of the Sierra Madre Occidental, in the states of Durango and Chihuahua, have reported similar changes in fire frequency since the 1950s (Fulé and Covington 1997, 1999; Heyerdahl and Alvarado 2003; Cortes-Montaño et al. 2012). In other sites, the greater amplitude in fire frequency intervals has resulted in an increase in quantity and continuity of fuel loads (White and Vankat 1993; Skinner et al. 2008). This, in turn, could favor larger and more severe fires in the future, which will have greater capacity for ecological and socioeconomic damage.

Pseudotsuga menziesii was part of the forest at the LS site, where some trees have survived numerous low-intensity fires over 400 years (Cerano-Paredes et al. 2012). This species is subject to special protection (SEMARNAT 2010) and could be in danger of disappearing in the Upper Nazas if stand-replacing fires occur.

\section{Management recommendations}

At the site level, a restoration goal for decision makers in the Upper Nazas watershed is to recover ecological 


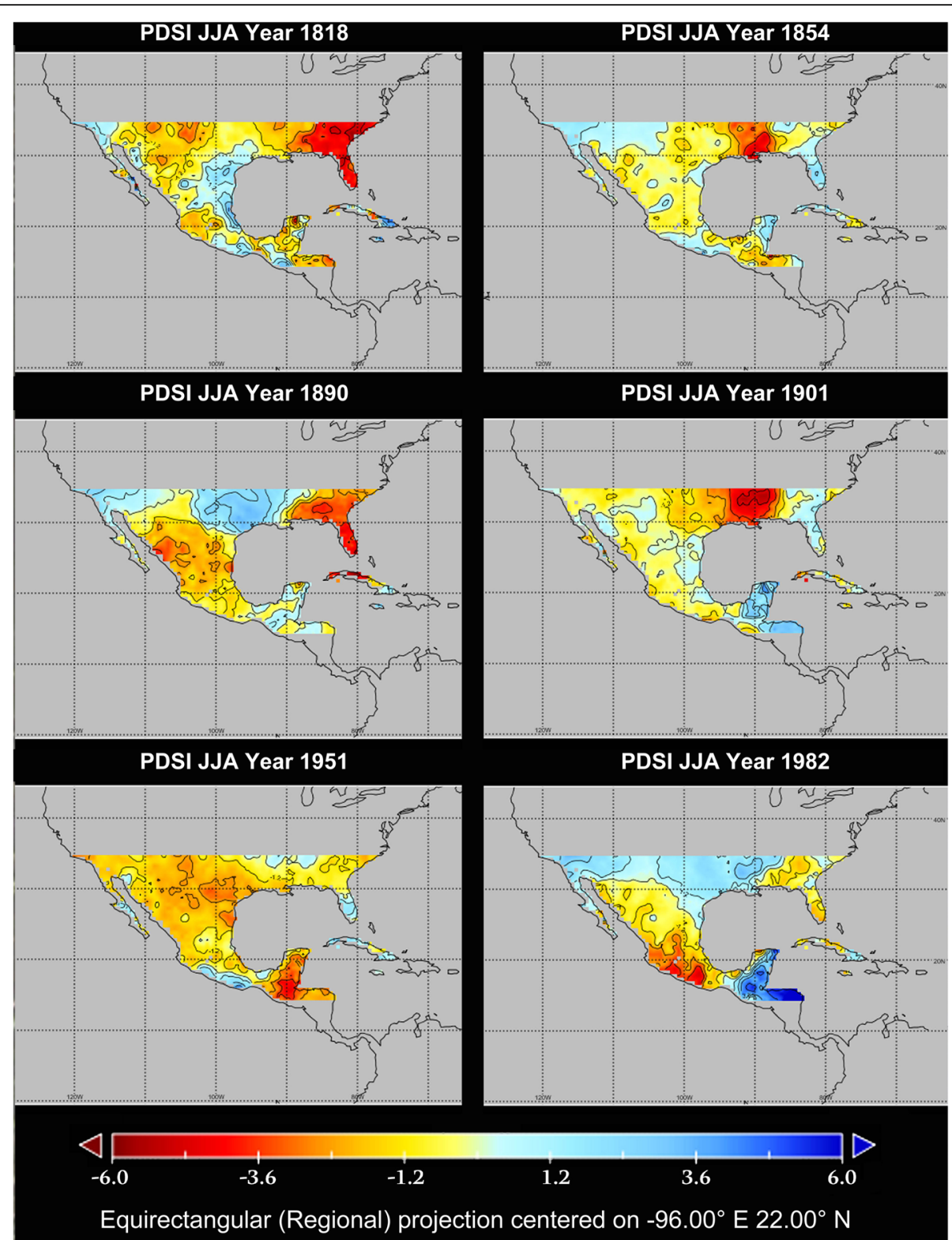

Fig. 7 Drought maps from the Mexican Drought Atlas (Stahle et al. 2016). The maps show dominant climatic conditions for the years 1818, 1854, 1890, 1901, 1951, and 1982, in which more trees were scarred by fires at the studied site at Ciénega de la Vaca, Durango, Mexico. JJA = June, July, August

conditions similar to those produced by historical fire frequencies, which could be accomplished by reintroducing surface fires to reduce current fire intervals to ranges like those determined by this study ( 3 to 8 years).

The significant influence of ENSO on the modulation of climatic variability in this region, as well as its influence on fire frequency, indicates that future ENSO cold phases may increase the risk of severe fires in this ecosystem. The increasing availability of weather information from buoys and satellites in the tropical Pacific, where the evolution of the ENSO phenomenon is monitored, allows us to have more precise knowledge of its behavior and derive models to predict its intensity. These forecasts, paired with region-specific knowledge of historical fire regimes, could allow us to advance management strategies in order to mitigate the impact of shifting trends on fire behavior at multiple scales.

\section{Conclusions}

Our results demonstrate a clear link between antecedent moisture one and two years preceding a fire, which leads to greater production of fine fuels, and dry conditions during subsequent dry years, and fire presence. Moreover, a significant change in fire frequency 
a
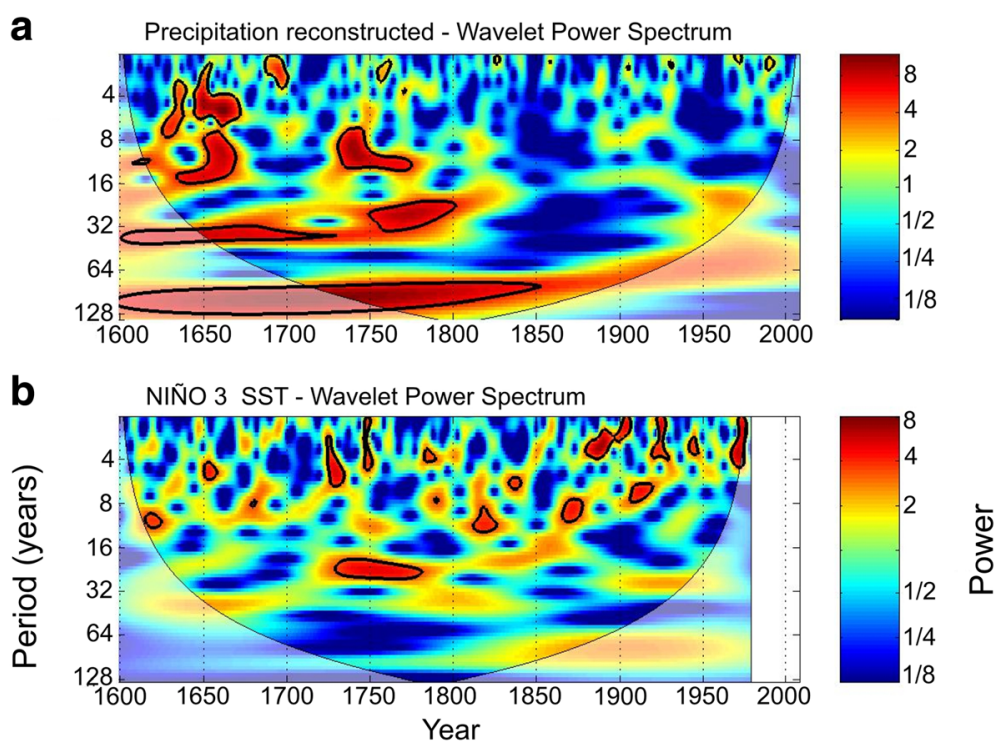

C

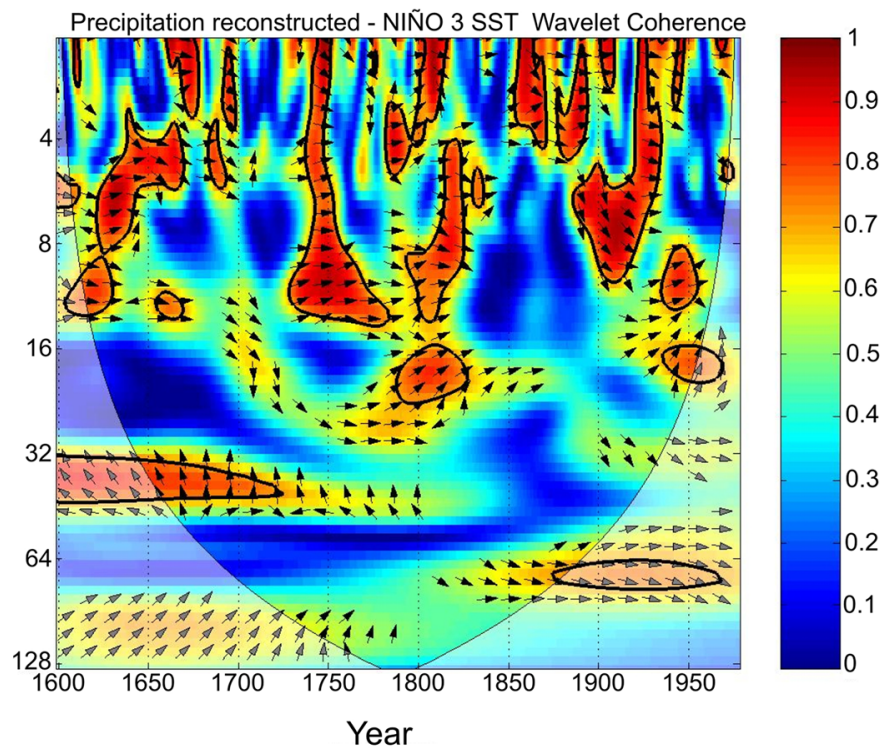

Fig. 8 The Wavelet Power Spectrum (Morlet) for Ciénega de la Vaca, Durango, Mexico, for the period from 1600 to 2000: a the reconstructed winter-spring precipitation time series and $\mathbf{b}$ the NIÑO 3 SST (December to February) time series, and $\mathbf{c}$ the wavelet coherence between both series. Black thick contours indicate the 95\% significance level using the red noise model, and the cone of influence is shown as a lighter shade. Vectors indicate the relative phase relationship between the NIÑO 3 SST and the reconstructed precipitation (horizontal arrow pointing right and left imply in-phase and antiphase relationships, respectively)

occurred in the Nazas watershed after the 1950s has increased the risk and susceptibility of these forests to maintain forest dynamics, hydrological functions, forest productivity, and other ecosystem services. Understanding historical fire regimes is fundamental in designing strategies for conservation and sustainable forest use. Fire frequencies must be maintained within the amplitude of their historical regime with the objective of preserving ecological benefits, reducing the risk of severe fires, and, consequently, supporting the adequate functioning of the ecological and hydrological processes taking place in the watershed. Then, our results on historical fire regimes are essential information for land managers and decision makers who are responsible for preserving these ecosystems and preventing potentially severe, catastrophic wildfires.

\section{Acknowledgements}

We thank P.Z. Fulé for his helpful reviews; J.M. Iniguez, C. Cortes Montaño, and other anonymous reviewers also provided helpful comments. 


\section{Funding}

This research was possible thanks to funding provided by the Inter-American Institute for Global Change Research (IAI). Project CRN \#2047 "Documenting, Understanding and Projecting Changes in the Hydrological Cycle in the American Cordillera," which was in turn funded by the US National Science Foundation (Grant GEO-0452325), and SEP-CONACYT through the project "Estudio de la relación clima-incendios en el norte-centro de México."

\section{Availability of data and materials}

The datasets used or analyzed during the current study are available from the corresponding author on reasonable request.

\section{Authors' contributions}

JC-P had major contribution to study conception and design, data collection, data analyses, and writing the manuscript, as well as minor contribution to securing funding support. JV-D had major contribution to study conception and design, securing funding support and writing the manuscript, as well as minor contribution to data collection and data analyses. LV-S had major contribution to study conception and design, data analyses, and writing the manuscript, as well as minor contribution to securing funding support and data collection. RC-M had major contribution to study conception and design, data collection and writing the manuscript, as well as minor contribution to securing funding support and data analyses. VOM-R had major contribution to study conception and design, data analyses, and writing the manuscript, as well as minor contribution to securing funding support and data collection VC$\mathrm{G}$ had major contribution to study conception and design, data collection and writing the manuscript, as well as minor contribution to securing funding support and data analyses. GE-A had major contribution to study conception and design, data collection and writing the manuscript, as well as minor contribution to securing funding support and data analyses. RDV-C had major contribution to study conception and design, data analyses and writing the manuscript, as well as minor contribution to securing funding support and data collection. All authors read and approved the final manuscript.

\section{Ethics approval and consent to participate}

Not applicable.

\section{Consent for publication}

Not applicable.

\section{Competing interests}

The authors declare that they have no competing interests.

\section{Publisher's Note}

Springer Nature remains neutral with regard to jurisdictional claims in published maps and institutional affiliations.

\section{Author details}

${ }^{1}$ Centro Nacional de Investigación Disciplinaria en Relación Agua-Suelo-Planta-Atmósfera del Instituto Nacional de Investigaciones Forestales Agrícolas y Pecuarias, Km. 6.5 Margen Derecha del Canal Sacramento, CP 35140 Gómez Palacio, Durango, Mexico. ${ }^{2}$ Instituto de Geografía, Universidad Nacional Autónoma de México, Ciudad Universitaria, 04510 Coyoacán, Ciudad de México, Mexico. ${ }^{3}$ Centro Regional Universitario Centro Norte, Universidad Autónoma Chapingo, Calle Cruz del Sur 100, Col. Constelación, CP 98085 Zacatecas, Zac., Mexico. ${ }^{4}$ Unidad Académica de Matemáticas, Universidad Autónoma de Zacatecas, Calzada Solidaridad s/n, CP 98064 Zacatecas, Zac., Mexico.

Received: 26 October 2018 Accepted: 31 October 2018 Published online: 16 April 2019

\section{References}

Arno, S.F., and K.M. Sneck. 1977. A method for determining fire history in coniferous forests of the Mountain West. Ogden: USDA Forest Service General Technical Report INT-42, Intermountain Forest and Range Experiment Station.

Aylward, B. 2005. Land use, hydrological function and economic valuation. In Forests, water and people in the humid tropics: past, present and future hydrological research for integrated land and water management, ed. M.
Bonnell and L. Bruijnzeel, 99-120. Cambridge: Cambridge University Press https://doi.org/10.1017/CBO9780511535666.012.

Baisan, C.H., and T.W. Swetnam. 1990. Fire history on a desert mountain range: Rincon Mountain Wilderness, Arizona, USA. Canadian Journal of Forest Research 20: 1559-1569 https://doi.org/10.1139/x90-208.

Baisan, C.H., and T.W. Swetnam. 1995. Historical fire occurrence in remote mountains of southwestern New Mexico and northern Mexico. In Brown JK, Mutch RW, Spoon CW, Wakimoto RH (technical coordinators) Proceedings: symposium on fire in wilderness and park management. USDA Forest Service General Technical Report GTR-INT-320, 153-156. Ogden: Intermountain Research Station.

Brown, P.M., M.A. Battaglia, P.J. Fornwalt, B. Gannon, L.S. Huckaby, C. Julian, and A S. Cheng. 2015. Historical (1860) forest structure in ponderosa pine forests of the northern Front Range, Colorado. Canadian Journal of Forest Research 45: 1462-1473 https://doi.org/10.1139/cjfr-2014-0387

Brown, P.M., and R. Wu. 2005. Climate and disturbance forcing of episodic tree recruitment in a Southwestern ponderosa pine forest. Ecology 86: 3030-3038 https://doi.org/10.1890/05-0034.

Bruijnzeel, L.A. 1990. Hydrology of moist tropical forests and effects of conversion, a state-of-knowledge review. Paris: UNESCO International Hydrological Programme.

Caso, M., C. González-Araham, and E. Ezcurra. 2007. Divergent ecological effects of oceanographic anomalies on terrestrial ecosystems of the Mexican Pacific coast. Proceedings of the National Academy of Sciences of the United States of America 104: 10530-10535 https://doi.org/10.1073/pnas.0701862104.

Cerano-Paredes, J., J. Villanueva-Díaz, and P.Z. Fulé. 2010. Reconstrucción de incendios y su relación con el clima para la reserva Cerró el Mohinora, Chihuahua. Revista Mexicana de Ciencias Forestales 1 (1): 63-74 [In Spanish].

Cerano-Paredes, J., J. Villanueva-Díaz, R.D. Valdez-Cepeda, J.G. Arreola-Ávila, and V. Constante-García. 2011. El Niño Oscilación del Sur y sus efectos en la precipitación en la parte alta de la cuenca del río Nazas. Revista Chapingo Serie Ciencias Forestales y del Ambiente 17 (SPE): 207-215 [In Spanish].

Cerano-Paredes, J., J. Villanueva-Díaz, R.D. Valdez-Cepeda, V. Constante-García, J.L. González-Barrios, and J. Estrada-Ávalos. 2012. Precipitación reconstruida para la parte alta de la cuenca del río Nazas, Durango. Revista Mexicana de Ciencias Forestales 3 (10): 7-23 [In Spanish].

Cook, E.R. 2000a. Niño 3 index reconstruction. International tree-ring data bank. IGBP PAGES/World Data Center for Paleoclimatology Data Contribution Series Number 2000-052. Boulder: NOAA/NGDC Paleoclimatology Program.

Cook, E.R. 2000b. North American drought variability PDSI reconstructions, IGBP PAGES/World Data Center for Paleoclimatology Data Contribution Series Number 2000-074. Boulder: NOAA/NGDC Paleoclimatology Program.

Cortes-Montaño, C., P.Z. Fulé, D.A. Falk, J. Villanueva-Díaz, and L.L. Yocom. 2012. Linking old-growth forest composition, structure, fire history, climate and land-use in the mountains of northern México. Ecosphere 3 (11): 1-16.

Costa, M.H. 2005. Large-scale hydrological impacts of tropical forest conversion. In Forests, water and people in the humid tropics: past, present and future hydrological research for integrated land and water management, ed. M. Bonnell and L. Bruijnzeel, 590-597. Cambridge: Cambridge University Press https://doi.org/10.1017/CBO9780511535666.030.

Daily, G.C. 2000. Management objectives for the protection of ecosystem services. Environmental Science \& Policy 3 (6): 333-339 https://doi.org/10.1016/S1462-9011(00)00102-7.

Descroix, L., J.L. González-Barrios, and J. Estrada-Ávalos, eds. 2004. La Sierra Madre Occidental, una fuente de agua amenazada. Gómez Palacio: Instituto Nacional de Investigaciones Forestales Agricolas y Pecuarias and Institut de Recherche pour le Développement [In Spanish].

Dieterich, J.H., and T.W. Swetnam. 1984. Dendrochronology of a firescarred ponderosa pine. Forest Science 30: 238-247.

Douglas, M.W., R.A. Maddox, K.W. Howard, and S. Reyes. 1993. The Mexican monsoon. Journal of Climate 6: 1665-1677 https://journals.ametsoc.org/doi/10.1175/1520-0442(1993)006\%3C1665: TMM\%3E2.0.CO;2.

Drury, S.A., and T.T. Veblen. 2008. Spatial and temporal variability in fire occurrence within the Las Bayas Forestry Reserve, Durango, Mexico. Plant Ecology 197 (2): 299-316 https://doi.org/10.1007/s11258-007-9379-5.

Falk, D.A., E.K. Heyerdahl, P.M. Brown, C. Farris, P.Z. Fulé, D. McKenzie, T.W. Swetnam, A.H. Taylor, and M.L. Van Horne. 2011. Multi-scale controls of historical forest-fire regimes: new insights from fire-scar networks. Frontiers in Ecology and the Environment 9 (8): 446-454 https://doi.org/10. 1890/100052.

Falk, D.A., E.K. Heyerdahl, P.M. Brown, T.W. Swetnam, E.K. Sutherland, Z. Gedalof, and T.J. Brown. 2010. Fire and climate variation in western North America 
from fire-scar and tree-ring networks. PAGES News 18 (2): 70-72 https://doi.org/10.22498/pages.18.2.70.

Farjon, A., J.A. Pérez de la Rosa, and T.B. Styles. 1997. Guía de campo de los pinos de México y América Central. England: Royal Botanic Gardens, Kew, and the Oxford Forestry Institute, Oxford University [In Spanish].

Farris, C.A., C.H. Baisan, D.A. Falk, and S.R. Yool. 2010. Spatial and temporal corroboration of a fire-scar-based fire history in a frequently burned ponderosa pine forest. Ecological Applications 20 (6): 1598-1614 https://doi.org/10.1890/09-1535.1.

Fulé, P.Z., and W.W. Covington. 1997. Fire regimes and forest structure in the Sierra Madre Occidental, Durango, Mexico. Acta Botanica Mexicana (41): 4379 https://doi.org/10.21829/abm41.1997.791.

Fulé, P.Z., and W.W. Covington. 1999. Fire regime changes in La Michilia Biosphere Reserve, Durango, Mexico. Conservation Biology 13 (3): 640-652 https://doi.org/10.1046/j.1523-1739.1999.97512.x.

Fulé, P.Z., J. Villanueva-Díaz, and M. Ramos-Gómez. 2005. Fire regime in a conservation reserve, Chihuahua, Mexico. Canadian Journal of Forest Research 35: 320-330 https://doi.org/10.1139/x04-173.

Fulé, P.Z., L.L. Yocom, C.C. Montaño, D.A. Falk, J. Cerano, and J. Villanueva-Díaz. 2012. Testing a pyroclimatic hypothesis on the Mexico-United States border. Ecology 93 (8): 1830-1840 https://doi.org/10.1890/11-1991.1.

García, M.E. 1987. Modificaciones al Sistema de Clasificación Climática de Köppen. Serie Libros Núm. 6. México D.F: Instituto de Geografía, Universidad Nacional Autónoma de México [In Spanish].

González-Elizondo, M.S., M. González-Elizondo, J.A. Tena-Flores, L. RuachoGonzález, and I.L. López-Enríquez. 2012. Vegetación de la Sierra Madre Occidental, México: una síntesis. Acta Botánica Mexicana (100): 351-403. [In Spanish] https://doi.org/10.21829/abm100.2012.40.

Grissino-Mayer, H.D. 2001. FHX2 — software for analyzing temporal and spatial patterns in fire regimes from tree rings. Tree-Ring Research 57: 115-124.

Grissino-Mayer, H.D., C.H. Baisan, and T.W. Swetnam. 1994. Fire history and age structure analyses in the mixed conifer and spruce-fir forests of Mount Graham. Arizona: Final report, Mount Graham Red Squirrel Study Committee, US Fish and Wildlife Service Phoenix.

Grissino-Mayer, H.D., and T.W. Swetnam. 2000. Century scale climate forcing of fire regimes in the American Southwest. The Holocene 10 (2): 213-220 https://doi.org/10.1191/095968300668451235.

Heyerdahl, E.K., and E. Alvarado. 2003. Influence of climate and land use on historical surface fires in pine-oak forests, Sierra Madre Occidental, Mexico. In Fire and climatic change in temperate ecosystems of the western Americas, ed. T.T. Veblen, W.L. Baker, G. Montenegro, and T.W. Swetnam, 196-217. New York: Springer-Verlag https://link.springer.com/chapter/10.1007/0-387-21710-X_7.

Holmes, R.L. 1983. Computer-assisted quality control in tree-ring dating and measurement. Tree-Ring Bulletin 43: 69-75.

IMTA [Instituto Mexicano de Tecnología del Agua]. 2009. Extractor rápido de información climatológica version 3.0 (ER/C III). Base de datos y software. Jiutepec: IMTA [In Spanish].

INEGI [Instituto Nacional de Estadística y Geografía] (2018) Simulador de flujos de agua de cuencas hidrográficas. http://antares.inegi.org.mx/analisis/red_hidro/siatl/\#. Accessed 5 May 2018. [In Spanish]

Iniguez, J.M., T.W. Swetnam, and C.H. Baisan. 2016. Fire history and moisture influences on historical forest age structure in the sky islands of southern Arizona, USA. Journal of Biogeography 43 (1): 85-95 https://doi.org/10.1111/jbi.12626.

Kaib, J.M. 1998. Fire history in riparian canyon pine-oak forests and the intervening desert grasslands of the Southwest borderlands: a dendroecological, historical, and cultural inquiry. Tucson: Thesis, University of Arizona.

Lertzman, K., J. Fall, and B. Dorner. 1998. Three kinds of heterogeneity in fire regimes: at the crossroads of fire history and landscape ecology. Northwest Science 72 (4): 23.

Loyer, J.Y., J. Estrada, R. Jasso, and L. Moreno, eds. 1993. Estudio de los factores que influencian los escurrimientos y el uso del agua en la región hidrológica 36. Gómez Palacio: Instituto Nacional de Investigaciones Forestales Agricolas y Pecuarias, Centro Nacional de Investigacion Disciplinaria en Relación Agua Suelo Planta Atmósfera, and Institut de Recherche pour le Développement [ln Spanish].

Magaña, R.V.O. 1999. Los impactos de El Niño en México. Ciudad de México: Universidad Nacional Autónoma de México, Centro de Ciencias de la Atmósfera, Dirección General de Protección Civil, Secretaría de Gobernación [In Spanish].

Magaña, V.O., J.L. Vásquez, J.L. Pérez, and J.B. Pérez. 2003. Impact of El Niño on precipitation in Mexico. Geofisica International 42 (3): 313-330.
Manson, R.H. 2004. Los servicios hidrológicos y la conservación de los bosques de México. Madera Bosques 10 (1): 3-20 [In Spanish]. https://doi.org/10.21829/myb.2004.1011276.

MathWorks (2002) MatLab software package version 6.5. MathWorks, Inc., Natick

Molina-Pérez, I.M., J. Cerano-Paredes, S. Rosales-Mata, J. Villanueva-Díaz, R. Cervantes-Martínez, G. Esquivel-Arriaga, and E. Cornejo-Oviedo. 2017. Historical fire frequency (1779-2013) in pine-oak forests in the community of Charcos, Mezquital, Durango. Revista Chapingo Serie Ciencias Forestales y del Ambiente 23 (1): 91-104 https://doi.org/10.5154/r.rchscfa.2016.03.017.

Myers, N. 1997. Environmental refugees. Population and Environment 19: 167-182 https://doi.org/10.1023/A:1024623431924.

Robinson, W.J., and R. Evans. 1980. A microcomputer-based tree-ring measuring system. Tree-Ring Bulletin 40: 59-64.

Sánchez-Cohen, I., M.A. Inzunza-Ibarra, G. Esquivel-Arriaga, J. Cerano-Paredes, M.A Velasquez-Valle, P. Bueno-Hurtado, and W. Ojedna-Bustamante. 2018. The impact of climatic patterns on runoff and irrigation water allocation in an arid watershed of northern Mexico. Meteorology Hydrology and Management 6 (2): 1-8 https://doi.org/10.26491/mhwm/90843.

Schweithelm, L. 2005. Forest people and changing tropical forestland use in tropical Asia. In Forests, water and people in the humid tropics: past, present and future hydrological research for integrated land and water management, ed. M. Bonnell and L.A. Bruijnzeel, 66-74. Cambridge: Cambridge University Press https://doi.org/10.1017/CBO9780511535666.009.

SEMARNAT [Secretaria de Medio Ambiente y Recursos Naturales]. 2010. Norma Oficial Mexicana NOM-059-SEMARNAT-2010. Protección ambiental-especies nativas de México de flora y fauna silvestres-categoría de riesgo y especificaciones para su inclusión o cambio-lista de especies en riesgo. México, Distrito Federal: Diario Oficial, segunda sección [In Spanish].

Skinner, C.N., J.H. Burk, M.G. Barbour, E. Franco-Vizcaíno, and S.L. Stephens. 2008. Influences of climate on fire regimes in montane forests of north-western Mexico. Journal of Biogeography 35: 1436-1451 https://doi.org/10.1111/j.1365-2699.2008.01893.x.

Stahle, D.W., E.R. Cook, D.J. Burnette, J. Villanueva, J. Cerano, J.N. Burns, R.D. Griffin, B.I. Cook, R. Acuña, M.C.A. Torbenson, and P. Sjezner. 2016. The Mexican Drought Atlas: tree-ring reconstructions of the soil moisture balance during the late pre-hispanic, colonial, and modern eras. Quaternary Science Reviews 149: 34-60 https://doi.org/10.1016/j.quascirev.2016.06.018.

Stahle, D.W., R.D. D'Arrigo, P.J. Krusic, M.K. Cleaveland, E.R. Cook, R.J. Allan, J. E. Cole, R.B. Dunbar, M.D. Therrell, D.A. Gay, M.D. Morre, M.A. Stokes, B.T. Burns, J. Villanueva-Díaz, and L.G. Thompson. 1998. Experimental dendroclimatic reconstruction of the Southern Oscillation. Bulletin of the American Meteorological Society 79 (10): 2137-2152 https://journals. ametsoc.org/doi/abs/10.1175/1520-0477(1998)079\%3C2137\%3AEDR OTS\%3E2.0.CO;2.

Stokes, M.A., and T.L. Smiley. 1968. An introduction to tree-ring dating. Chicago: University of Chicago Press.

Swetnam, T.W. 1993. Fire history and climate change in giant sequoia groves Science 262: 885-889 https://doi.org/10.1126/science.262.5135.885.

Swetnam, T.W., and C.H. Baisan. 1996. Fire histories of montane forests in the Madrean Borderlands. In Ffolliott PF, DeBano LF, Baker MB, Gottfried GJ, SolisGarza G, Edminster CB, Neary DG, Allen LS, Hamre RH (technical coordinators) Proceedings of a symposium: effects of fire on Madrean Province ecosystems. USDA Forest Service General Technical Report RM-GTR-289, 15-36. Fort Collins: Rocky Mountain Research Station.

Swetnam, T.W., and C.H. Baisan. 2003. Tree-ring reconstructions of fire and climate history in the Sierra Nevada and southwestern United States. In Fire and climatic change in temperate ecosystems of the western Americas, ed. T.T. Veblen, W.L. Baker, G. Montenegro, and T.W. Swetnam, 158-195. New York: Springer-Verlag https://link.springer.com/chapter/10.1007/0387-21710-X_6.

Swetnam, T.W., and J.L. Betancourt. 1990. Fire-Southern Oscillation relations in the southwestern United States. Science 249: 1017-1020 https://doi.org/10.1126/science.249.4972.1017.

Swetnam, T.W., and J.L. Betancourt. 1998. Mesoscale disturbance and ecological response to decadal climatic variability in the American Southwest. Journal of Climate 11: 3128-3147 https://journals.ametsoc.org/doi/full/10.1175/15200442\%281998\%29011\%3C3128\%3AMDAERT\%3E2.0.CO\%3B2.

Taylor, A.H., and R.M. Beaty. 2005. Climatic influences on fire regimes in the northern Sierra Nevada mountains, Lake Tahoe Basin, Nevada, USA. Journal of Biogeography 32 (3): 425-438 https://doi.org/10.1111/j.1365-2699.2004.01208.x. 
White, M.A., and J.L. Vankat. 1993. Middle and high elevation coniferous forest communities of the North Rim region of Grand Canyon National Park, Arizona, USA. Vegetatio 109 (2): 161-174 https://doi.org/10.1007/BF00044748. Wolter, K., and M.S. Timlin. 2011. El Niño/Southern Oscillation behaviour since 1871 as diagnosed in an extended multivariate ENSO index (MEI. ext). International Journal of Climatology 31 (7): 1074-1087 https://doi.org/10.1002/joc.2336.

Yocom, L.L., P.Z. Fulé, P.M. Brown, J. Cerano-Paredes, J. Villanueva-Díaz, D.A. Falk, and E. Cornejo-Oviedo. 2010. El Niño Southern Oscillation effect on a fire regime in northeastern Mexico has changed over time. Ecology 91 (6): 1660-1671 https://doi.org/10.1890/09-0845.1.

Yocom, L.L., P.Z. Fulé, D.A. Falk, C. García-Domínguez, E. Cornejo-Oviedo, P.M. Brown, J. Villanueva-Díaz, J. Cerano-Paredes, and C. Cortes-Montaño. 2014. Fine-scale factors influence fire regimes in mixed-conifer forests on three high mountains in Mexico. International Journal of Wildland Fire 23 (7): 959-968 https://doi.org/10.1071/WF13214.

\section{Submit your manuscript to a SpringerOpen ${ }^{\circ}$ journal and benefit from:}

- Convenient online submission

- Rigorous peer review

- Open access: articles freely available online

High visibility within the field

- Retaining the copyright to your article

Submit your next manuscript at $\boldsymbol{\nabla}$ springeropen.com 